\title{
PARTICIPATORY BUDGETING: CASE STUDY OF POSSIBLE CAUSES OF FAILURES
}

\author{
Michal Soukop ${ }^{1}$, Pavel Šaradín ${ }^{2}$, Markéta Zapletalová ${ }^{3}$
}

\begin{abstract}
Participatory budgeting is perhaps the most widespread and popular form of democratic innovation (DI). It is often identified as an appropriate tool to deepen the democracy at the local level. The text shows that this is not always the case, as some elected officials may use it as a innovation "façade" or its design suffers from various forms of imperfections leading to its failure to be implemented. The authors focus on the practice of participatory budgeting and its failures in the Czech Republic. Through the empirical testing of causal mechanism, the article reveals the main causes of that failure, in the case of its implementation in Prague 7 borough. The mechanism presented is based on the theory-testing minimal process-tracing design in which part of the findings of the previous research have been tested. It also attempts to support empirically only the significant steps of the mechanism between cause and outcome. In particular, the three scope conditions are tested: political support, sufficient funding for participatory budgeting and the existence of a source of know-how. Authors conclude that in the selected case, there was a domino effect of failure, with successive failures in all observed conditions, which ultimately led to a complete brake of causal mechanism and failure of participatory budgeting tool.
\end{abstract}

KEY WORDS: Participatory budgeting, Failure, Czech Republic, Local government, Process-tracing.

\section{INTRODUCTION}

General assumption is that most local politicians follow their clear objective: developing communities and maintaining or improving communities' environment, in order to best meet citizens' needs. Various tools and practices for achieving this goal are used, the best known of which is called "democratic innovations" (DIs). These are understood as

\footnotetext{
${ }^{1}$ Faculty of Arts, Palacký University in Olomouc, Křížkovského 513/12, 77900 Olomouc, Czech Republic. E-mail: michal.soukop@upol.cz, ORCID: 0000-0003-4482-0003.

${ }^{2}$ Faculty of Arts, Palacký University in Olomouc, Křížkovského 513/12, 77900 Olomouc, Czech Republic. E-mail: pavel.saradin@upol.cz, ORCID: 0000-0003-0470-5430.

${ }^{3}$ Faculty of Arts, Palacký University in Olomouc, Křížkovského 513/12, 77900 Olomouc, Czech Republic. E-mail: m.zapletalova@upol.cz, ORCID: 0000-0003-2645-8944.
} 
tools that help to deepen participation, increase interest in local politics, and also promote a pro-democratic mindset. All known typologies (for example, Smith, 2009; Geissel, 2012; Elstub, Escobar, 2017, 2019) consider participatory budgeting as one of the most used tools. It is a very proven and popular tool with elected officials as well as residents. It is possible to use them to measure its benefits and effectiveness: in the first phase, the authors choose a project to finance, in the second stage they implemented it, and finally used it. If all processes are transparent, this tool is very useful.

The academic literature and research focus mainly on the implementation and functioning of democratic innovations through case studies or comparisons. Although they point to their varying effectiveness or success rates, research on failed democratic innovations has been somewhat marginalised. In practice, the authors encounter cases where political representation, NGOs or citizens try to introduce democratic innovation that cannot be achieved or that is no longer in operation after a certain period of time. Just as it may be useful to follow best practices, it may also be useful to analyse failures and provide answers to the following questions: Why do participatory budgets fail? Especially when it comes to the discovery of the causes of these failures. Unless there is a reason to ensure that the future attempts avoid these causes and that relevant actors know how to set rules for effective democratic innovation. In short, to avoid their failure.

The author's effort in this research concentrates on analysis of the causes of PB failures. The article is relying on a series of failed PB cases that were followed in the Czech Republic. The aim of the study is to explain the failure of a specific PB using the Prague 7 case through a causal mechanism. In the Czech Republic, about 120 participation budgets are in operation (data for 2020), only a small fraction shows some dysfunctions, but some have disappeared over time.

The issue of participatory budgeting has been extensively studied in the literature at the international level (Dias, 2019). This is not the case in the Czech environment, except for isolated studies (Zapletalová, Soukop, Šaradín, 2020). This may be because the participation budgeting in the Czech Republic is not as widespread as in Western Europe and other countries. The Czech Republic's experience with PBs started in 2012. The first studies on this subject were methodological and educational. They promoted participatory budgeting, how to introduce and support them (Černý, 2016; Vojtíšková, 2016).

If we compare the situation regarding participatory budgeting in the Czech Republic with that of its two post-communist neighbours, we can 
observe the following: Poland started the practice of PB already in 2011 (Sopot) and the number increased to around 80 the following year. PB "has grown more and more popular and by amendment of the Act on Local Government introduced in 2017, organisation of participatory budgeting is obligatory for all urban counties starting in 2019" (Madej, 2019, p. 261). In Slovakia, a unique attempt to introduce PB also appeared in 2011 (the capital city of Bratislava), whereby it was interesting that "the funds for the first cycle of participatory budgeting in the amount of 15 thousand euros were provided by sponsors and were therefore not public resources". (Klimovský et al., 2021, p. 106). PB became popular mainly through the NGO "Utópia.sk" and is operated in more than 60 cities and several municipalities. The Czech Republic's experience with PBs started in 2012; since then, the practice has been tried in a number of cities / towns and municipalities. In 2020 , approximately 120 PBs were implemented. All three countries have experienced budgets that failed. The most known case is that of the Slovak capital Bratislava ${ }^{4}$.

\section{DEMOCRATIC INNOVATIONS FAKE AND FAILED?}

As suggested in the Introduction, while the study of the success of democratic innovations is a mainstream focus of research in case-based studies, the question of why democratic innovations fail in a specific context (especially if they do not have the desired effect) is crucial, but it is still neglected. Authors of constitutive texts (Smith, 2009; Geissel, 2012; Newton, 2012) have addressed the question of how to assess democratic innovations and their impact through defining common criteria for their evaluation. However, evaluating the effect of democratic innovations is very complicated, with problems on the research side playing a role, where analytical and methodological pitfalls are evident, as well as the question of quantifiability. Another problem can be defined as a political-institutional aspect, in which the set institutional conditions, as well as the behaviour and attitudes of political representatives, play a role.

According to Newton (2012, p. 13), there is no or little effect of DI on several reasons. First, it may not be properly applied ("the logic and methods that underpin it may be defective"), or it may be that possible desirable

\footnotetext{
${ }^{4}$ The Bratislava experiment was short-lived and was terminated after several years (Murray Svidroňová, Klimovský, forthcoming). In relation to this fact, Hrabinová (2018, pages not marked) states that the PB ceased to exist in 2014 as a consequence of failure to implement certain projects. At present, it is once again functional.
} 
effects have been "negatified" by "the actions of interested parties", such as "governments, parties, bureaucrats or opposing interest groups". Newton uses the term "placebo effect". This, according to him, is "caused not by the innovation itself but simply because the authorities have taken trouble to try to reach out to citizens and express an interest in their opinions. Warm and fuzzy feelings and the belief that things are getting better, even if they are not, may be what research measures, rather than any specific benefit flowing from specific innovation".

The question of politicians' true political will to introduce democratic innovations, not just to use them as a catchy marketing slogan on civic participation, remains neglected. The problem of tension between the representative role of elected representatives in relation to democratic innovations and enhancing the role of the citizens is highlighted by Thompson (2019, pp. 255-256): "Regardless of whether one supports a limited or more expansive role for citizens between elections, the ad hoc nature of many democratic innovations suggests that elected representatives do not yet see an ongoing role for democratic innovations as part of representative democracy." Thompson gave two types of motivations for elected representatives to participate in democratic innovations, although the lines between them in the real world are much more blurry. The first type is "normative motivations", which Thompson associated with the politician's ideological party background, or it may be an expression of the politician's personal values and beliefs. In the case of the second type, these are "instrumental motivations" "where elected representatives use democratic innovations to achieve particular results or outcomes they value". This instrumental type of motivation includes mostly desirable aspects. Thus, politicians' intentions are associated, for example, with a desire to build legitimacy and trust, be responsive to citizens' activities, or share responsibility with citizens.

Thompson (2019) also referred to the critical approach of Walker, McQuarrie and Lee (2015) who pointed out that political elites have adapted to the challenges of civic participation, and a participation is used as a "management tool" rather than a democratisation method. "The (E)lite rule is reorganized to accommodate greater openness and participation without disrupting hierarchies and power relations" (Walker et al. in Thompson, 2019, p. 260).

With a certain amount of cynicism, one can say that advocating and promoting citizen participation and involvement is perceived by local politicians as fashionable, demanded, and valued. However, a genuine 
concern on the part of politicians is often completely absent, and it is all about the attractive rhetoric aimed at the media and voters. The appropriation of the content and effects of democratic policy innovations leads to a "façade" (Spada, Ryan, 2017) of participation aimed only at creating a sense of legitimacy and excusing for its own political decisions. The result is "façade" democratic innovations that do not achieve their objectives and are only passed off as DIs because they improve the media image of politicians and give citizens a false sense of participation.

Support for the thesis that politicians do not care much about sharing power with citizens is also suggested by research by Hendriks and LeesMarshment (2018), which focused on the question of how political leaders (at the level of state ministers) view and value public input in their decisionmaking work. Research has shown that most leaders see public engagement as a means of gaining "diverse views" and more through informal methods such as "informal conversations with individual citizens that occur behind the scenes, after an event, in a meeting, or in everyday public settings such as a local market" rather than "structured engagement" (Hendriks, LeesMarshment, 2018, pp. 9-13).

De Renzio, Spada, and Wampler (2019) in the case of participatory budgets claim that "they work best in the initial years, when scale is still limited, and citizens are galvanized by its novel approach." In their text, they discussed participatory budgeting in Brasil after 30 years. They examined the reasons for some budget failures, including "participation fatigue" or delay in implementing ideas and lack of feedback. The authors also presented the three arguments that contribute to the stability of the participation budget, namely a) political support, b) ensuring that there is enough money to fund projects, and c) making the projects acceptable and sustainable in scope.

During the application of participatory budgeting, other imperfections may be encountered (Klimovský et al. 2021, pp. 56-69) that may manifest themselves in lower trust in the process, respectively, lead to its failure. The first problem may be related to the question of the method of selection of participants, in case of participatory budgeting the process is usually very open and based on self-selection (Elstub, Escobar, 2017). Therefore, only those interested in public affairs are involved in the voting process. These tend to be educated people rather than those with less education, and middle and upper class rather than low-income or unemployed. These characteristics of the participants may influence the selection of projects that suit these groups interests and are close to their homes (Featherstone, 2018). Conversely, parts of the city in which they do not live, are still 
neglected or develop much slower. There can be many more causes of failures, for example, a change in political representation (Rodgers, 2010), poor technical preparation, uninformed or poorly informed citizens, inappropriate voting procedures, excessive bureaucratization, etc. Recently, the COVID-19 pandemic has also had an impact on participatory budgeting conduct (Bardovič, Gašparík, 2021).

\section{DATA, METHODOLOGY AND CONDITIONS DISCUSSION}

In 2021, the research team prepared a detailed mapping of participatory budgeting projects in the Czech Republic. The work was based on the research of studies of non-profit organizations, bachelor and master theses, as well as on studying the websites of municipalities and towns, or their social networks. This effort was preceded by the collection of baseline data, whereby the team monitored the participatory budgeting process between 2016 and 2020 across the entire population of municipalities with expanded powers (MEP's, $n=205$ ). After being supplemented by other municipalities according to the experience of the researchers, the team identified a total of 113 PBs in 2020. The focus was exclusively on municipal and town budgets, including town boroughs. No focus was on county budgets. The core interest was on questions as when the budget was introduced in a given municipality, number of residents of the given municipality, number of projects submitted in any given year, number of projects supported, form of voting, and how many citizens voted on the projects. The resulting data corpus, as the basis of our research on participatory budgeting, also serves as a source database for this article in the search for failing PBs. From this corpus, examples of failures in the participatory budgeting are Prague 7 (2014), Rumburk (2016), Nelahozeves, Pržno, Př́bor, Třanovice (established by the project), Dobřejovice (2016) and Zbuzany (2018).

To explain in detail the causes of the failure of the PB at the local level, the research team chose the case of one of the first attempts to implement PB in the Czech Republic - in the Prague 7 borough. The selected case is suitable for a detailed examination firstly because it is easier to retrospectively obtain relevant evidence, and secondly, due to the accumulation of the assumed scope conditions (see below for more details). This allows the relevance of these conditions to be tested only in one case.

The case of Prague 7 has already been described in general and in very brief detail in some publications (see for example Menšíková, Bouchal and Rákos, 2018; the topic is also mentioned in several diploma theses). 
However, no work has tried to identify and document empirically the causal mechanism in operation. The research team tried to do this by using elements of the process-tracing method according to the methodology of Beach and Pedersen (2018, 2019; see also Bennett, Checkel, 2014; Mazák, 2017 etc.), which was successfully applied to address the issue of PB in research in recent years (see for example Zapletalová, Soukop, Šaradín, 2020). Process-tracing as a case studies method is based on ontological logic and mechanistic approach, where the cause (the decision to implement PB) and outcome (confirmed implementation of $\mathrm{PB}$ in municipal practice) of the investigated process are known to us and are present in the investigated process. The main attention is, however, paid to the use of empirical evidence to prove the sequence of steps in the causal mechanism linking the cause and outcome. It is in this causal mechanism that the causes of possible failures of PB should be sought. Nevertheless, it should be emphasized that the process-tracing method tests a specific assumed causal mechanism, but this does not exclude the possibility of alternative causal mechanisms. Even with a looser concept of the rules and requirements of the method, multicausality or equifinality cannot be excluded, for example, when trying to capture some branching processes. This must be taken into account in the draw up of conclusions.

The mechanism presented here is based on the theory-testing minimal process-tracing design, where the authors attempt to test and empirically support only the significant steps of the causal mechanism. In this case, especially partial findings from previous research, that work with the assumed conditions for the proper functioning of the causal mechanism, are tested (see, for example De Renzio, Spada, Wampler, 2019; Zapletalová, Soukop, Šaradín, 2020; Šaradín, Soukop, Zapletalová, and Hurtíková, forthcoming). Some intermediate steps are left uncovered. The basic premise of the constructed mechanism is the expected failure of one or more scope conditions, which will lead to failure of the entire mechanism. For the analysis of the Prague 7 PB failure case, the article presents a very simplified causal mechanism diagram in Figure 1. Here, the individual substeps of the causal mechanism in the form of the initiation of the process and its preparation (including, for example, the official approval of the PB by the representative bodies) are "wrapped up" and not further discussed in favour of a more detailed examination of the key position of the scope (contextual) conditions necessary for the proper functioning of the causal mechanism. At the same time, the authors present the empirical evidence relevant to each part of the mechanism in Table 1 at the end of the article. 
Figure 1: Simplified diagram of the PB implementation process - the key role of scope conditions

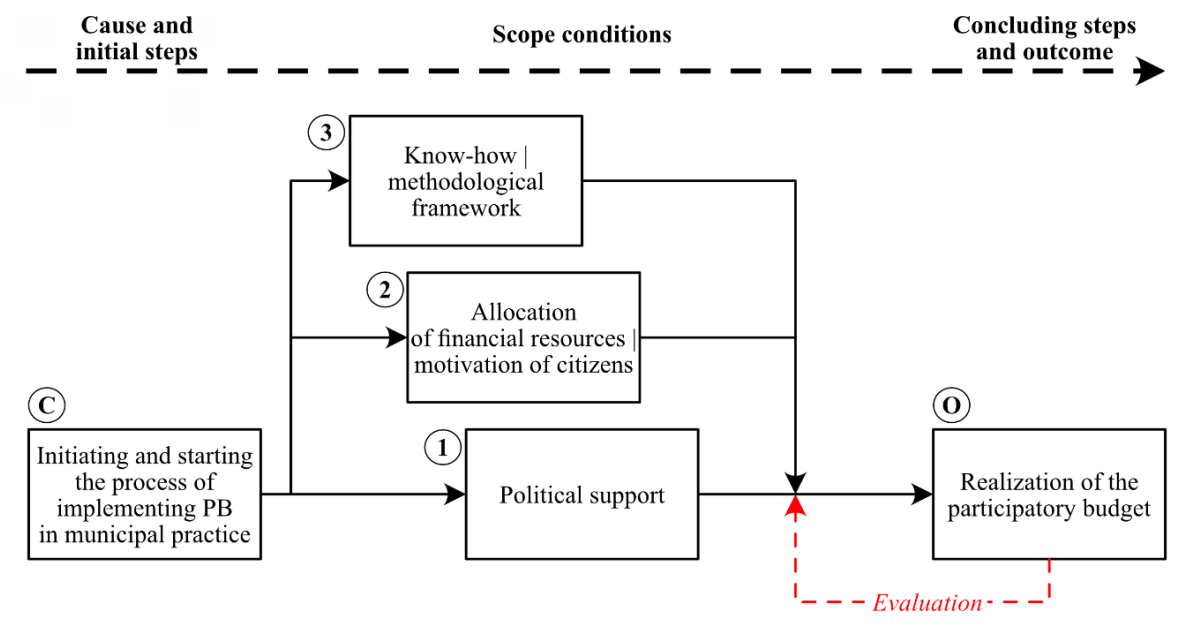

Source: Authors own elaboration

A key scope condition is political support for the introduction of PB in the municipality, discussed several times in the existing literature (see Menšíková, Bouchal and Rákos, 2018; De Renzio, Spada, Wampler, 2019). The importance of political support is indirectly shown also in the authors' other research, which points to the need to change political representatives at the local level in the absence of political support for the implementation of DIs (Šaradín, Soukop, Zapletalová, and Hurtíková, forthcoming) or other research that points to a "novelty factor" in the normal turnover of municipal representative bodies in elections, which may lead to political support for DIs by new representatives (see Hurtíková, Soukop, 2019). Simple logic also speaks for the key position of political support. Even if there is a demand, e.g., from citizens or civil society organizations, it is practically impossible to officially introduce a PB in a municipality without one of the official representatives, most often the mayor, vice-mayor, or councillor - supporting these efforts. In less cases, the initiative of a councillor is sufficient, but even here it is necessary for the executive part of the municipality to be on our side.

The second necessary scope condition is the allocation of a sufficiently large amount of money from the municipal budget for PB. Here, the article draws primarily on the authors' own research (Šaradín, Soukop, Zapletalová, and Hurtíková, forthcoming), which using regression models based on 
examples of the Czech Republic and Slovakia, supports the importance of sufficient economic bases, both in terms of the direct allocation of funds to projects supported by the PB and in terms of the economic situation of the municipalities themselves. The economic dimension of successful PB retention in practice is also discussed by De Renzio, Spada and Wampler (2019). Examples of real practice are also noteworthy. For example, the Czech town of Rumburk introduced a PB in 2016 and allocated CZK 300,000 . The disappearing participation with the resulting repair of a single small religious monument, i.e., the apparent demotivation of the citizens and the low allocation of funds also led to a loss of political support for the implementation of the PB in the following years. There are illustrative examples also in Slovakia. In Bratislava, after the introduction of PB in 2011, they faced a long-term low share of allocated money. For example, the originally announced 1 percent of the budget (about EUR 2 million) was reduced to EUR 46,000 in 2013. The amount is only allocated during the process, it is not fixed in advance. This low amount, together with lack of transparent and standardized procedures, eventually led to disputes between the municipality and the cooperating organisation "Utopia", which contributed to the implementation of the project through its expertise and know-how. "Utopia" insisted on public voting, while the municipality insisted only on online voting. The demotivation of citizens, together with the loss of know-how after the departure of "Utopia" from the project at the turn of $2013 / 2014$, also led to a loss of political support and the abandonment of the conventional PB concept. And the line of argumentation could continue like this.

Some analyses also try to calculate these amounts per capita or allocate them as percentage of the budget, but it is not appropriate to determine them in this way. The amount of allocated funds for the PB should not be regarded as an economic indicator, but as a subjective-psychological factor that motivates citizens to participate actively in the PB process. In some municipalities, the tradition of civic participation may be so rooted that the allocated amount may be relatively small, but still lead to active participation by many citizens. On the contrary, in municipalities, where the only motivation factor is the amount of money involved, even a relatively large amount may not be sufficient. It is absolutely necessary to evaluate this individually in the context of the municipality in question.

The third scope condition tested by this research is the existence of knowhow on PB issues and an appropriately set methodological framework for the implementation PB in the municipality. The authors generally do not 
think that this condition is a necessary one, as it is not present in all the cases of failed PB that were under research, but it is a significant factor influencing the failure of the two necessary conditions described above, especially in the case of Prague 7, but also in many cases analysed in detail in other research, for example, PB implementation processes in the borough of Bratislava - Nové Mesto, Czech town of Zlín or Polish town of Rybnik (see Šaradín, Soukop, Zapletalová, and Hurtíková, forthcoming). If a municipality does not cooperate, for example, with a civil society organization that has already helped to implement PB in other municipalities and does not have its own know-how, this may lead to an inappropriately set methodology for implementing PB, which will affect the outcome of such efforts and may ultimately lead to the abandonment of the concept of PB at the municipal level. As we will demonstrate below, it is these scope conditions and their failure that cause the causal mechanism to break down and the concept of PB to be abandoned (not only) in Prague 7.

\section{CASE STUDY OF PRAGUE 7- WHY PB FAILED?}

PB in Prague 7 has its origins in a proposal made by the only communist councillor at the time, Miroslava Moučková, in 2014 (C1) ${ }^{5}$, with the apparent support of the "Alternativa Zdola" ("Alternative from below" in translation) association (C2). The latter was founded by economist Ilona Švihlíková, who is known in the Czech environment for her strong left-wing views and criticism of neoliberal economics and globalisation. Some commentators have described her as controversial, but in their views and therefore in the activities of the aforementioned association, elements of the New Left could be observed in the form of support for the development of local communities and modern cooperativism as an economic alternative to neoliberalism. This may play a role in the distinctly right-wing Prague, along with a strong membership link with the Communist Party of Bohemia and Moravia in the above-mentioned association, as will be discussed below. Miroslava Moučková's proposal argued for "an effort to alleviate citizens' dissatisfaction with politics, and at the same time to change passive voters into active ones who will not succumb to populist campaigns" (C3). This motion was eventually supported on 17th February 2014 by councillors across all parties represented on the local council (C4, C5, C1). An amount of CZK 1 million (both the maximum amount per project and the total maximum amount) was allocated to $\mathrm{PB}(\mathrm{C} 4, \mathrm{C} 6)$, which according to the $\mathrm{PB}$

${ }^{5}$ The identifier in parentheses refers to the empirical evidence in Table 1. 
Implementation Principles (approved on 28th April 2014; C7) was to be distributed to the projects selected by the citizens of the borough first in a preselection at traditional public meetings and then in a separate voting. Already in July 2014, the possibility to submit a proposal for a project to a specially prepared email address or to the Environmental Department of the borough office by 15th September was launched. The projects could not be in violation of Czech and EU legislation, had to be related to investment or sporting events, and had to be implemented only on the territory (and land) of the municipality borough. The formal fulfilment of these conditions was validated by the Healthy City and Local Agenda 21 Commission (C6, C7, C8).

The officially validated projects have been presented to the public on 22nd September at the traditional annual "10 Problems of Prague 7" meetings, where the citizens, after discussing and identifying the problems of the borough, could vote by stickers in a preselection on 13 projects from a total of 20 submitted. Six projects were selected (C8, C9). Already here a very low attendance of citizens was noted (only 33 citizens voted), which could lead to a non-representative preselection of projects. After the local elections in October 2014, the selected projects were subsequently made available to all eligible citizens of the borough for voting either at the borough office or at its information centres (C10) between 3rd and 14th November. A total of 66 citizens voted, of whom only 62 were valid, of a total of over 40,000 citizens of the borough. Only one project, a sports field in Holešovice, was awarded the following year for its implementation. The newly elected municipal leaders announced directly the necessary change to the PB Principles (C11), which occurred in 2016-2017, when the original concept was completely abandoned and the PB was launched in local primary schools.

At first glance, it may appear that the political leaders of the borough have cancelled the PB due to lack of interest from the citizens. However, this is only a partial external imprint of the causal mechanism. On closer examination, a cascading failure of individual scope conditions can be observed. In fact, probably nobody asked why citizens were not interested in participating in the PB at all. Why has the new political representation that emerged from the 2014 elections not identified the problem and tried to restart the PB throughout the neighbourhood after the necessary changes, instead of taking the whole concept directly to primary schools?

Although, it is impossible to reliably identify the actual cause of citizens' non-participation in voting on PB projects, it is likely to be a negative synergy of several different factors. First of all, the PB Implementation Principles 
document was approved relatively late, only a few months before the actual implementation of the PB. This would not have been a problem if the municipality officials had made an active effort to explain PB's mechanisms and rules to citizens. However, the promotion of PB was limited to laconic formal announcements and copying the rules from the council's resolutions on the website, Facebook, and possibly through the "Alternativa Zdola" association and their representatives. Prague 7 switched to a new website a few years ago, so the research team members tracked the status of the website in 2014 using the "Internet Archive Wayback Machine", and also the borough's Facebook profile. The borough posted information about the possibility to participate in the PB on its website on 2nd July (1a) and posted the same information on its Facebook profile on 11th July (1b). Further information related to PB was posted on the Facebook profile on 11th September (1c) and on the borough's website on 12th September (1d). This was an invitation to the Healthy City public forum " 10 problems of Prague 7", giving the opportunity to learn about the projects and to vote on the project's preselection (see also C10). The last information about the possibility of voting was posted on the Facebook profile of Prague 7 on 30th October it presented titles of the six preselected projects and informed about the possibilities of voting (1e). No information about the voting on the website was detectable in the period 1-17th October and 12-24th November. It is possible that information appeared in the form of updates between these dates, but even in the interim period, the information could not be found on the electronic notice board of the borough. It was not until 10th December when the results of the vote were presented on the Facebook profile (1f). Although it is very likely that information about the possibility of voting and participation in the PB process in general was part of, e.g., the municipality borough's magazine "Hobulet" (available retrospectively only until 2015) and the "Alternativa Zdola" initiative itself states that it distributed several hundred leaflets $(1 \mathrm{~g})$, it is apparent that the promotion of PB was absolutely minimal, very passive, and limited to formalistic announcements.

The activity of the "Alternativa Zdola" association is necessarily limited to its target group of strongly left-wing citizens in strongly rightwing Prague (as mentioned above). Furthermore, information on the Association's website was limited to articles from its representatives, and social media posts appeared to be shared only in a specific social bubble. All announcements, including those of the borough, were made in a very unfriendly spirit, with formalistic text, without any effort in graphic design or in a simplified explanation of the PB mechanism to the citizens. In view of 
the fact that this was the first actual attempt to implement the real PB in the municipal practice of the Czech Republic, failure could be expected.

However, if it were not linked to the ongoing local elections, promotion itself would probably not play an important role. For some incomprehensible reasons, the vote on the projects was not merged with the voting dates of the local elections on 10th and 11th October but was scheduled for the period of formation of the new local executive a few weeks after the elections. The vote itself was then held only in person in the borough offices and information centres (2a). One of the sources (2b) also mentions the possibility of voting on the borough's website, but it stayed unconfirmed from other sources, and the official information did not mention any such thing. The rule on the need to propose investment (or sport) events, that were projected positively by the borough and other actors as investments in the future instead of one-off events, contributed to the inappropriate methodology, but citizens pointed out, for example, it was not possible to renovate dilapidated playgrounds using PB funds (2c). The scope condition of an appropriate methodology was virtually inexistent at this point.

In this case, other scope conditions were necessary to maintain the PB implementation process. As mentioned above, the allocated amount of CZK 1 million may not be too small. However, as the author of the PB proposal, Miroslava Moučková, herself stated (see link from C1), the electoral campaign was very aggressive, and reactions of some citizens in the Facebook profile announcements on the possibility to vote on projects (very negative reactions referring both to the small amount of money and to the failure to solve other pressing problems of the borough) (see post from 1e) indicate that citizens had no other motivation to actively participate than the amount of money itself, which proved to be insufficient in such an environment. This seems to have led to the failure of the second scope condition as well.

It is evident from the statements of the new municipal leaders emerging from the elections that with weak participation of citizens in voting political support for such activities would disappear completely (3a, C11). And this has indeed happened. Only replacing the PB with its adapted form in primary schools in a de facto attempt to "start again from the bottom up" by promoting PB among the youngest generation and their parents, with the possibility of restoring the PB to the level of the entire borough at the appropriate time, it can be a certain positive (3b, 3c).

These factors combined to create the proverbial lethal cocktail that led to a cascading failure of scope conditions and a break in the causal mechanism. The poorly set PB methodology with its inappropriate implementation 
deadline, the unfriendly voting model, and the completely unmanaged communication of the at the time still new participatory tool caused that the only motivating factor suddenly became the allocated amount of money, which, however, was insufficient in the context of the borough affected by community problems. As a result, the participation of citizens in the voting process was poor. Consequently, political leaders evaluated this in the assessment of the PB which took place and abandoned the concept of PB or turned it into a PB in primary schools. PB at the level of the entire borough, however, lost political support, and thus the last scope condition necessary for the causal mechanism to work.

Such a failure of scope conditions is not only the case of Prague 7, as shown above. It can be said that the failure of PB that occurred in Prague 7 is far from unique and It is driven by transferable scope conditions that must be met to enable the standard causal mechanism to function and support the implementation of the PB in municipal practice.

Table 1: Empirical evidence for the failure of the PB implementation process in Prague 7

\begin{tabular}{ccl}
\hline $\begin{array}{c}\text { Jurisdiction } \\
\text { of evidence }\end{array}$ & $\begin{array}{c}\text { Evidence } \\
\text { identifier }\end{array}$ & \multicolumn{1}{c}{ Quotations and references } \\
\hline $\begin{array}{c}\text { Cause and } \\
\text { initial steps }\end{array}$ & C1 & $\begin{array}{l}\text { "In the outgoing term I was the only person to } \\
\text { advocate for a participatory budget in the KSČ } \\
\text { council, and yet my proposal received the support } \\
\text { across the political spectrum." } \\
\text { https://www.parlamentnilisty.cz/arena/politici- } \\
\text { volicum/Mouckova-KSCM-V-Praze-7-obcane- } \\
\text { navrhovali-a-vybirali-projekty-337238 }\end{array}$
\end{tabular}

C2 "Miroslava Moučková ... after her election to the Council in 2010, she began to promote it [PB] on the basis of an initiative by the organization Alternativa zdola. It helped her to draw up the concept [of PB] ..." (p. 46) https://dspace.cuni.cz/bitstream/ handle/20.500.11956/2116/120258984. pdf? sequence $=1$ \&isAllowed $=y$

C3 "New ways need to be found to move people from passively accepting the various protest campaigns of those who seek to be elected to councils on a wave of populism to become actively involved in decisions on where they live."

http://alternativazdola.cz/tomas-vokoun-prvnivlastovka-participativniho-rozpoctu-v-cr/ 
C4 Resolution of the Municipal Council No. 008/14-Z; 17th February 2014

C5 "...the proposal of Councillor Miroslava Moučková (KSČM) was voted in favour by councillors from all clubs in the council - ČSSD, ODS, SZ-SNK ED, TOP 09 - and nobody opposed the rules when they were approved."

https://blisty.cz/art/75036-participativnirozpocet-pronikl-mezi-volebni-temata.html

C6 "...[borough] approved that, later this year, citizens will have the opportunity to suggest where the million crowns will go."

https://www.praha.eu/jnp/cz/o_meste/ mestske_casti/praha_7/navrhnete_jak_vyuzit_ milion_z_rozpoctu $\$ 5465$-export.html

C7 Resolution of the Municipal Council No. 0035/14-Z; 28th April 2014

C8 Summary information on the project submission, evaluation, and approval process. https://denikreferendum.cz/clanek/18641participace-na-praze-7

C9 Information on statistics on submitted, assessed and pre-selected projects.

http://alternativazdola.cz/podzimni-vlastovkajara-participace/

C10 "After the traditional meeting of the Healthy Cities Forum in late September, citizens will be informed of the submitted proposals. Everyone will receive a sticker to vote on the board for the proposal they like the best. Depending on the number of votes received, the proposals will be included in a poll in which the citizens of Prague 7 will be able to vote in the second and third week of November at the Prague 7 municipal office or at information centres."

https://www.praha.eu/jnp/cz/o_meste/ mestske_casti/praha_7/navrhnete_jak_vyuzit_ milion_z_rozpoctu $\$ 5465$-export.html 
C11 "I would like to thank everyone who gave their time to this survey. In the future, we want to involve citizens in the participatory budget in a more effective way. Therefore, we will be preparing new rules for next year. However, we will definitely meet with the author of the winning proposal and seek ways to bring her project to life, said the Mayor of Prague 7, Mgr. Jan Čižinský." (the mayor's media statement also mentioned in the officially announced results of the vote)

http://alternativazdola.cz/praha-7-vysledkyhlasovani-o-vyuziti-participativni-castirozpoctu/

\begin{tabular}{|c|c|c|}
\hline \multirow[t]{7}{*}{$\begin{array}{l}\text { First scope } \\
\text { condition }\end{array}$} & $1 a$ & $\begin{array}{l}\text { News on the borough's website from 2nd July } \\
\text { (available via the Internet Archive) }\end{array}$ \\
\hline & $1 b$ & $\begin{array}{l}\text { Facebook post from 11th July (Prague } 7 \\
\text { profile) }\end{array}$ \\
\hline & $1 c$ & $\begin{array}{l}\text { Facebook post from 11th September (Prague } \\
7 \text { profile) }\end{array}$ \\
\hline & $1 d$ & $\begin{array}{l}\text { News on the borough's website from 12th } \\
\text { September (available via the Internet Archive) }\end{array}$ \\
\hline & $1 \mathrm{e}$ & $\begin{array}{l}\text { Facebook post from } 30 \text { th October (Prague } 7 \\
\text { profile) }\end{array}$ \\
\hline & 1f & $\begin{array}{l}\text { Facebook post from 10th December (Prague } \\
7 \text { profile); see also background document for } \\
\text { the council meeting } \\
\text { https://www.praha7.cz/wp-content/uploads/ } \\
\text { councilResolution/Resolutions/25546/3-15- } \\
\text { anketa_participativni_rozpocet_2014.pdf }\end{array}$ \\
\hline & $1 \mathrm{~g}$ & $\begin{array}{l}\text { "[Activists] distributed hundreds of information } \\
\text { materials, especially leaflets, and explained the } \\
\text { meaning of participatory budgeting, its history, } \\
\text { and its spread in the world and in Slovakia." } \\
\text { http://alternativazdola.cz/podzimni-vlastovka- } \\
\text { jara-participace/ }\end{array}$ \\
\hline $\begin{array}{l}\text { Second scope } \\
\text { condition }\end{array}$ & $2 a$ & $\begin{array}{l}\text { The same information as 1e, or C8 and many } \\
\text { others. }\end{array}$ \\
\hline
\end{tabular}


2b "Citizens will be able to participate in the poll during November via the borough's website or at the information centres of the borough and at the Prague 7 municipal office," said Lukáš Janů, Coordinator of the Healthy City Project and Local Agenda 21."

https://www.metro.cz/sedmicku-trapivykaly-i-malo-lavicek-na-nejvetsi-problemyradnici-upozornilo-verejne-forum-gy7-/praha. aspx?c=A140923_143903_co-se-deje_hyr

2c "... the rules for the participatory budget were incorrect and inaccurately set from the outset funding could only be used for new investment projects, but the Prague 7 land registry did not contain sufficient land for new playgrounds." (from the "Hobulet" magazine of the municipal borough, p. 23)

https://www.praha7.cz/wp-content/ uploads/2017/08/2016_05-1.pdf

\section{Third scope condition}

3a

“... however, only a few dozen people participated in the entire process and the result was only general proclamations without concrete projects... Our goal is to involve citizens in the preparation of the entire budget, not just a fraction of it." (answer of $\mathbf{F}$. Vosecký, Councillor for Sport, Local Agenda 21 and Business Support to citizens' criticism of the non-implementation of PB in the "Hobulet" magazine of municipal borough; June 2016) https://www.praha7.cz/wp-content/ uploads/2017/08/2016_06-1.pdf

3b "... we will implement the participatory budget project this year, but first in the Prague 7 primary schools. Thisyear, the borough allocated CZK 50,000 for each school from its budget for this project. This money will be decided directly by the pupils of our primary schools and their parents ... We see it as a way to test the process, to make it more popular, and at the same time to arouse children's interest in their surroundings. Once it is over, we will evaluate it and consider extending it to the whole borough." (answer of F. Vosecký, Councillor for Sport, Local Agenda 21 and Business Support to citizens' criticism of the non-implementation of PB in the "Hobulet" magazine of municipal borough; March 2017)

https://www.praha7.cz/wp-content/ uploads/2017/08/2017_03-1.pdf 
3c "... in this way, we will be able to spread the principles and idea of $P B$ throughout the entire municipality and bring it closer to the pupils of primary schools (and their parents), who in the near future will decide the shape of the entire Prague 7 ... The medium-term objective of the Prague 7 municipality is to implement $P B$ at the level of the entire municipality. By first introducing this process through primary schools, sufficient awareness of it will be spread, which will also have a positive effect on participation in municipal PB."

Explanatory Memorandum for the 2016 change to the PB implementation principles.

\begin{tabular}{|c|c|c|}
\hline $\begin{array}{l}\text { Conclusion } \\
\text { steps and } \\
\text { outcome }\end{array}$ & $\mathbf{0}$ & $\begin{array}{l}\text { For outcome evidence, see C11 or 1e, for } \\
\text { "evaluation loop" evidence, see C11, or } 3 \mathrm{a} \text {. }\end{array}$ \\
\hline
\end{tabular}

Note: Only basic evidence, selected quotations, and references are presented.

Source: Authors own elaboration.

\section{CONCLUSION}

In order to analyse the causes of PB failures at local level and answer the article's research questions, the authors have chosen the participatory budgeting case in Prague 7 borough. This was the case of one of the first attempts to introduce participatory budgeting in the Czech Republic, which failed in the first year of its implementation. Although this attempt was mentioned several times in literature, until now, no in-depth analysis of this failure has been carried out. In this article, the authors have used the processtracing method to fill in this gap. The article identifies three scope conditions for participatory budgeting to be functional, which were also tested. These conditions are political support, a sufficient allocation of funds, which functions as a subjective-psychological factor and in the communities where participation is not sufficiently developed, it can be used as a motivator. The third condition under research was the existence of sufficient know-how in the field of $\mathrm{PB}$ and the suitability of the methodological framework for the PB implementation in the municipality. Testing of this particular case showed that it was the combination of failures in domino effect style in all these three factors that led to the final project failure. The PB project was processed based on poor methodology, and neither the incentive of large amount of money allocated to the procedure led to higher participation. Finally, the budget also completely lost political support, the last condition for the causal mechanism to work. 
This study is the rare attempt to explain why specific PB implementation processes in the Czech Republic have failed. However, analyses that explain the failures of PBs are also rather absent in international research, which often focuses solely on successful cases and, for example, their impact on the strengthening of democracy at the local level of the concerned countries. However, it is essential to bring the knowledge about the causes of its failures in order to ensure the proper functioning of such democratic innovations, because municipalities that fail to use these tools are more likely to have problems with citizen participation and pro-democratic mindset of citizens. It is necessary to discuss and understand the reasons and errors, not only those mentioned in this article, so that the lack of implementation does not discredit and jeopardize the idea of civic participation as a whole.

\section{Acknowledgement:}

This research was supported by the Czech Science Foundation [grant number 17-20569S].

\section{REFERENCES}

BARDOVIČ, J. and GAŠPARÍK, J. (2021). Enablers of Participatory Budgeting in Slovakia During the COVID-19 Pandemic. In: Scientific Papers of the University of Pardubice, Series D: Faculty of Economics and Administration. [online]. Vol. 29, No. 1. DOI: https://doi.org/10.46585/sp29011248 [Accessed 31st August 2021].

BEACH, D. and PEDERSEN, R. B. (2018). Selecting Appropriate Cases When Tracing Causal Mechanisms. In: Sociological Methods \& Research. [online]. Vol. 47, No. 4, pp. 837-871. DOI: https://doi. org/10.1177\%2F0049124115622510 [Accessed 31st August 2021].

BEACH, D. and PEDERSEN, R. B. (2019). Process-Tracing Methods: Foundations and Guidelines. Michigan: University of Michigan Press. 328 pp. DOI: https://doi.org/10.3998/mpub.10072208.

BENNETT, A. and CHECKEL, J. T. (2014). Process-Tracing: From Metaphor to Analytical Tool. Cambridge: Cambridge University Press. DOI: https:// doi.org/10.1017/CB09781139858472.

ČERNÝ, V. (2016). Metodika tvorby participativního rozpočtu pro města v ČR. Praha: Agora CE. 47 pp.

DE RENZIO, P., SPADA, P. and WAMPLER, B. (2019). Paradise Lost? The Crisis of Participatory Budgeting in Its Own Birthplace. In: International Budget Partnership. 25th November [Blog]. Available at: https:// 
www.internationalbudget.org/2019/11/paradise-lost-the-crisis-ofparticipatory-budgeting-is-its-own-birthplace/ [Accessed 31st August 2021].

DIAS, N. (2019). Participatory Budgeting World Atlas 2019. [online]. Available at: https://www.pbatlas.net/pb-world-atlas-2019.html [Accessed 31st August 2021].

ELSTUB, S. and ESCOBAR, O. (2017). A Typology of Democratic Innovations. In: Political Studies Association's Annual Conference. [online]. Glasgow. Available at: https://www.psa.ac.uk/sites/default/files/ conference/papers/2017/A\%20Typology\%20of\%20Democratic\%20 Innovations\%20-\%20Elstub\%20and\%20Escobar\%202017.pdf [31st August 2021].

ELSTUB, S. and ESCOBAR, O. (2019). The Handbook of Democratic Innovation and Governance. Cheltenham: Edward Elgar Publishing. 624 pp. DOI: https://doi.org/10.4337/9781786433862.

FEATHERSTONE, L. (2018). Participatory Budgeting: Why not Fix Everyone's Sink? [online]. Available at: https://shelterforce.org/2018/06/05/ participatory-budgeting-why-not-fix-everyones-sink/ [Accessed 31st August 2021].

GEISSEL, B. (2012). Democratic Innovations: Theoretical and Empirical Challenges of Evaluation. In: Geissel, B. and Newton, K. eds. Evaluating Democratic Innovations. London and New York: Routledge, pp. 209-214. HENDRIKS, C. M. and LEES-MARSHMENT, J. (2018). Political Leaders and Public Engagement. In: Political Studies. [online]. pp. 1-21. DOI: https:// doi.org/10.1177\%2F0032321718791370 [Accessed 31st August 2021]. HRABINOVÁ, A. (2018). Metodika hodnotenia procesov participatívneho rozpočtovania pre mapovanie skúseností s participatívnym rozpočtovaním $v$ prostredí miestnej územnej samosprávy na Slovensku. [online]. Available at: https://www.minv.sk/swift_data/source/rozvoj_ obcianskej_spolocnosti/participacia/vystupy_np_parti/Metodika\%20 hodnotenia $\% 20$ procesov $\% 20$ participativneho $\% 20$ rozpoctovania_ Alexandra\%20Hrabinova.pdf [Accessed 31st August 2021].

HURTÍKOVÁ, H. and SOUKOP, M. (2019). Participative and Deliberative Democracy on the Local Level: How the Political Characteristics of Municipalities in the Czech Republic Relate to the Use of Selected Democratic Innovation within Their Teritory? In: Lex Localis. [online].Vol. 17, No. 2. DOI: https://doi.org/10.4335/17.2.369-393(2019] [Accessed 31st August 2021]. 
KLIMOVSKÝ, D. et al. (2021). Participatívne rozpočtovanie (kontexty, modely a paktické skúsenosti). Bratislava: Wolters Kluwer SK. 144 pp.

MADEJ, M. (2019). Participatory Budgeting in the Major Cities in Poland Case Study of 2018 Editions. In: Politics in Central Europe. [online]. Vol. 15, No. 2. DOI: https://doi.org/10.2478/pce-2019-0017 [Accessed 31st August 2021].

MAZÁK, J. (2017). Process Tracing: Zkoumání kauzality v případových studiích. In: Sociológia. [online]. Vol. 49, No. 1, pp. 55-80. Available at: https://www.sav.sk/journals/uploads/03061031Mazak\%20-\%20 zalomena\%20-\%200K.pdf [Accessed 31st August 2021].

MENŠÍKOVÁ, V, BOUCHAL, P. and RÁKOS, T. (2018). Propojit Prahu: Současná praxe participace a vize pro její systémové zakotvení. Praha: Společnost Demokracie. $180 \mathrm{pp}$.

MURRAY SVIDROŇOVÁ, M. and KLIMOVSKÝ, D. (forthcoming). Participatory Budgeting in Slovakia: Recent Development, Present State, and Interesting Cases. In: De Vries, M., Nemec, J. and Špaček, D. eds. International Trends in Participatory Budgeting: Between Trivial Pursuits and Best Practices. London: Palgrave Macmillan. pp. 247-269. DOI: https://doi. org/10.1007/978-3-030-79930-4_13.

NEWTON, K. (2012). Curing the Democratic Malaise with Democratic Innovations. In: Geissel, B. and Newton. K. eds. Evaluating Democratic Innovations. London and New York: Routledge, pp. 3-20.

RODGERS, D. (2010). Contingent Democratisation? The Rise and Fall of Participatory Budgeting in Buenos Aires on JSTOR. In: Journal of Latin American Studies. [online]. Vol. 42, No. 1, pp. 1-27. D0I: https://doi. org/10.1017/S0022216X10000039 [Accessed 31st August 2021].

ŠARADÍN, P., SOUKOP, M, ZAPLETALOVÁ, M. and HURTÍKOVÁ, $\mathrm{H}$. (forthcoming). Challenging Citizens. Democratic Innovations at the Local Level: The Case Study of the Czech Republic, Slovakia, and Poland. Cham: Springer.

SMITH, G. (2009). Democratic innovations. Designing Institutions for Citizen

Participation. New York: Cambridge University Press. DOI: https://doi. org/10.1017/CBO9780511609848.

SPADA, P. and RYAN, M. (2017). The Failure to Examine Failures in Democratic

Innovations. In: Politics Symposium. [online]. Vol. 50, No. 3, pp. 772-778. DOI: https://doi.org/10.1017/S1049096517000579 [Accessed 31st August 2021].

THOMPSON, N. (2019). The Role of Elected Representatives in Democratic Innovations. In: Elstub, S. and Escobar, O. eds. Handbook of Democratic 
Innovations and Governance. Cheltenham and Northampton: Edward Elgar Publishing, pp. 255-268. DOI: https://doi.org/10.4337/9781786 433862.00027.

VOJTÍŠKOVÁ, K. (2016). Česká cesta k participativnímu rozpočtování. In: Smart Cities. [online]. Available at: https://www.scmagazine.cz/ casopis/02-16/ceskacesta-k-participativnimu-rozpoctovani_locale_cs/ [Accessed 31st August 2021].

WALKER, E. T., MCQUARRIE, M. and LEE, C. W. (2015). Rising Participation and Declining Democracy. In: Lee, C. W., McQuarrie, M. and Walker, E. T. eds. Democratizing Inequalities. Dilemmas of the New Public Participation. New York and London: New York University Press, pp. 3-23. DOI: https:// doi.org/10.18574/nyu/9781479847273.003.0001.

ZAPLETALOVÁ, M., SOUKOP, M. and ŠARADÍN, P. (2020). Praxe participativních rozpočtů $\mathrm{v}$ České republice. Př́padová studie obce $\mathrm{s}$ rozšířenou působností Semily. In: Sociológia - Slovak Sociological Review. [online]. Vol. 52, No. 2, pp. 180-200. DOI: https://doi.org/10.31577/ sociologia.2020.52.2.8 [Accessed 31st August 2021]. 